\title{
Correlation between numbers of cells in human dental pulp and age: Implications for age estimation
}

Article in Archives of oral biology · March 2017

DOI: 10.1016/j.archoralbio.2017.03.018

CITATIONS

0

7 authors, including:

Mohammad Zakir Hossain

Matsumoto Dental University

27 PUBLICATIONS 88 CITATIONS

SEE PROFILE

\section{Fathilah Abdul razak}

University of Malaya

88 PUBLICATIONS 303 CITATIONS

SEE PROFILE
READS

61

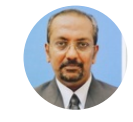

Phrabhakaran Nambiar

University of Malaya

75 PUBLICATIONS 348 CITATIONS

SEE PROFILE

Marina Mohd Bakri

University of Malaya

26 PUBLICATIONS 113 CITATIONS

SEE PROFILE

Some of the authors of this publication are also working on these related projects: 


\section{Accepted Manuscript}

Title: Correlation between numbers of cells in human dental pulp and age: Implications for age estimation

Authors: Mohammad Zakir Hossain, Sulinda Daud, Phrabhakaran Nambiar, Fathilah Abdul Razak, Norintan Ab-Murat, Roslan Saub, Marina M. Bakri

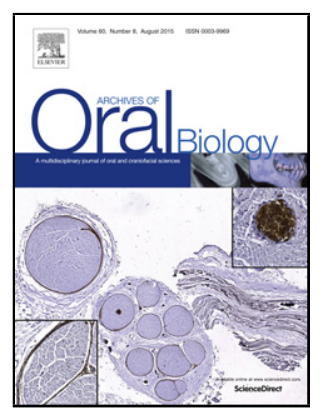

PII:

DOI:

Reference:

S0003-9969(17)30095-X

To appear in: $\quad$ Archives of Oral Biology

Received date: $\quad 15-8-2016$

Revised date: 21-3-2017

Accepted date: $\quad$ 23-3-2017

Please cite this article as: Hossain Mohammad Zakir, Daud Sulinda, Nambiar Phrabhakaran, Razak Fathilah Abdul, Ab-Murat Norintan, Saub Roslan, Bakri Marina M.Correlation between numbers of cells in human dental pulp and age: Implications for age estimation.Archives of Oral Biology http://dx.doi.org/10.1016/j.archoralbio.2017.03.018

This is a PDF file of an unedited manuscript that has been accepted for publication. As a service to our customers we are providing this early version of the manuscript. The manuscript will undergo copyediting, typesetting, and review of the resulting proof before it is published in its final form. Please note that during the production process errors may be discovered which could affect the content, and all legal disclaimers that apply to the journal pertain. 
Correlation between numbers of cells in human dental pulp and age: implications for age estimation

Mohammad Zakir Hossain ${ }^{\text {ab* }}$ Sulinda Daud ${ }^{c}$, Phrabhakaran Nambiar ${ }^{\mathrm{d}}$, Fathilah Abdul Razak ${ }^{\mathrm{a}}$, Norintan Ab-Murat ${ }^{\mathrm{e}}$, Roslan Saub ${ }^{\mathrm{e}}$, Marina M. Bakri ${ }^{\mathrm{a}}$

${ }^{a}$ Department of Oral and Craniofacial Sciences, Faculty of Dentistry, University of Malaya, Kuala Lumpur, Malaysia

${ }^{b}$ Department of Oral Physiology, Faculty of Dentistry, Matsumoto Dental University, Nagano, Japan

${ }^{\mathrm{c}}$ Dental Faculty, Segi University College, Petaling Jaya, Malaysia

${ }^{\mathrm{d}}$ Department of Oro-maxillofacial Surgical \& Medical Sciences, Faculty of Dentistry, University of Malaya, Kuala Lumpur, Malaysia

${ }^{\mathrm{e}}$ Department of Community Oral Health and Clinical Prevention, University of Malaya, Kuala Lumpur, Malaysia

* Corresponding author:

Mohammad Zakir Hossain, BDS, PhD

Department of Oral Physiology, School of Dentistry, Matsumoto Dental University, 1780 Gobara Hirooka, Shiojiri, Nagano 399-0781, Japan

Tel: +81- 263-51-2053

Fax: +81- 263-51-2053

E-mail: zakir@po.mdu.ac.jp, zakir@um.edu.my 


\title{
Highlights
}

- Correlating dental pulp cells with age

- First attempt in estimating age using dental pulp cells

- Regression equations using odontoblasts and subodontoblasts cell number can be used to predict age with some limitations.

\begin{abstract}
Objective: The aim of this study was to investigate correlations between dental pulp cell count of odontoblasts, subodontoblasts and fibroblasts and age, within different age groups. Formulation of regression equations using the dental pulp cell count for predicting age was attempted.
\end{abstract}

Design: Eighty-one extracted teeth were grouped into two age groups (6-25 years, 26-80 years). The teeth were demineralized and histological sections were prepared for cell count. Regression equations were generated from regression analysis of cell count and tested for age estimation.

Results: The number of dental pulp cells were found to increase until around the third decade of life and following this, the odontoblasts and subodontoblasts cell numbers began to decline while the fibroblasts seemed to remain almost stationary. The Pearson correlation test revealed a significant positive correlation between the cell number for all type of cells and age in the 6-25 years group $(r=+0.791$ for odontoblasts, $r=+0.600$ for subodontoblasts and $r=+0.680$ for fibroblasts). In the 26-80 years age group, a significant negative correlation of the odontoblasts ( $\mathrm{r}=$ $-0.777)$ and subodontoblasts $(r=-0.715)$ with age was observed but for fibroblasts, the correlation value was negligible $(r=-0.165)$. Regression equations generated using odontoblasts and subodontoblasts cell number were applicable for age estimation. The standard error of estimates (SEEs) were around \pm 5 years for $6-25$ years and \pm 8 years for $26-80$ years age groups. The mean values of the estimated and chronological ages were not significantly different. 
Conclusions: A significant correlation between the cell count of odontoblasts and subodontoblasts with age was demonstrated. Regression equations using odontoblasts and subodontoblasts cell number can be used to predict age with some limitations.

Keywords: dental pulp; aging; odontoblasts; subodontoblasts; fibroblasts

\section{Introduction}

Understanding the effects of aging on the dental tissues have become increasingly important as there have been an increase in the life expectancy of individuals. In addition, the number of patients retaining their teeth throughout their later life has also increased. One of the dental pulp cells that has been widely studied is the odontoblasts. It is an important cell and has a life-long function as it contributes to the formation of both primary and secondary dentine (Baume, 1980; Stanley, White \& McCray, 1966). When a tooth is exposed to an external stimuli and depending on the degree of tooth injury, the odontoblast cells may secrete tertiary dentine or may die and thus other undifferentiated pulp cells, such as sub-odontoblasts or fibroblasts may be recruited to take part in the tooth repair process. This is possible because these cells differentiate to become odontoblastlike cells that secrete tertiary dentine (Goldberg \& Smith, 2004; Tziafas \& Kodonas, 2010).

Apart from the hard tissue forming cells of odontoblasts and subodontoblasts, the fibroblasts is mainly involved in the maintenance of the dental pulp matrix by producing the extracellular matrix and collagen. In addition, the fibroblasts also play an important role in tissue repair (Nanci, 2012). Understanding the age related changes that these cells undergo are crucial as the functions of these 
cells may be affected. Much of our knowledge on the aging features of the pulpal cells are based on ultrastructural studies of the odontoblast cells that were carried out both in rats (Takuma \& Nagai, 1971) and humans (Couve, 1986; Couve \& Schmachtenberg, 2011). In humans, the life cycle of the odontoblasts has been described as pre-odontoblasts, secretory, transitional and aged odontoblasts (Couve, 1986). The relationships between age and cell densities of the dental pulp cells as well as their morphological changes have also been reported (Murray, Matthews, Sloan \& Smith, 2002; Murray, Stanley, Matthews, Sloan \& Smith, 2002). However, the use of dental pulp cell counts for estimating age has not been reported before. Estimations of the developmental age of children and adolescents can be based on the development and eruption stages of deciduous and permanent teeth. (Demirjian, Goldstein \& Tanner, 1973; Logan \& Kronfeld, 1933; Moorrees, Fanning \& Hunt, 1963) Following the eruption of permanent teeth, age estimates are based on biological changes in the structure of the tooth. The first scientific method of age assessment based on biological changes in the teeth was reported by Gustafson (Gustafson, 1950). The changes observed were attrition of the tooth surface, gingival recession, transparency of the root, root resorption, apposition of the secondary cementum at the root apex and an increase in the secondary dentine thickness. Gustafson's method has been examined many times over the years, (Johanson, 1971; Metzger, Buchner \& Gorsky, 1980; Pillai \& Bhaskar, 1974; Solheim, 1992; Whittaker \& Bakri, 1996). Other methods of age estimation have been developed but many of these studies are still based on the Gustafson's method, employing either individual or combined age-related parameters (Brkic, Milicevic \& Petrovecki, 2006; Grosskopf \& McGlynn, 2011; Schmitt, SalibaSerre, Tremblay \& Martrille, 2010). The purpose of this study was to correlate and determine the applicability of dental pulp cell counts namely odontoblasts, sub-odontoblasts and fibroblasts for age estimation. 


\section{Materials and Methods}

In this study, eighty-one extracted teeth that were not affected by caries or those requiring extraction for orthodontic purposes were obtained from the Department of Oral and Maxillofacial Surgery, Faculty of Dentistry, University Malaya. Each of the extracted tooth was stored in individual bottle containing phosphate buffered saline and labelled with the donor's age. The teeth included in this study consisted of teeth with completed root formation. All of the patients involved in this study had complete dental records and gave consent for their extracted teeth to be used for the study. This present study fulfilled the requirements of the Medical Ethics Committee of the Faculty of Dentistry, University of Malaya.

The teeth were grouped according to their age in two age groups; 6-25 years and 26-80 years. Each tooth was washed in phosphate buffered saline and cut at the apical one third of the root to facilitate the entry of the fixative into the dental pulp. The tooth was cut using the microslicer (Malven, England) before placing the remaining portion of the tooth in $10 \%$ buffered formalin (v/v) for one day. Following fixation of all teeth in $10 \%$ buffered formalin, all teeth were then decalcified using $5 \%$ formic acid and the formic acid solution was changed every three days (Daud, Nambiar, Hossain, Saub, Ab-Murat, Asma' M, Razak \& Bakri, 2016). The decalcification process was undertaken until radiographic evidence showed complete decalcification. Following this, the teeth were subjected to routine processing for histological examination before embedding in paraffin wax, cut at $5 \mu \mathrm{m}$ and stained with hematoxylin and eosin. Images of the pulp were captured using the digital microscope eyepiece, resolution 640 x 480, which was attached to the Microscope Olympus CHK-B145 at x4 to x100 magnifications and connected to a computer. The images obtained from the computer were then used to enumerate the dental pulp cell count. A "Ulead 
Photo Explorer version 7.0" software was used to magnify the images obtained from the histology slides. The odontoblasts were identified as columnar shaped cells with basally placed nuclei and are found lining the outermost region of the pulp beneath the predentine. The subdontoblast cells are located below the odontoblasts while the fibroblasts from the pulp core were included for the cell count.

The number of cells between two age groups were compared using t-test. Pearson correlation test was performed to evaluate the relationship between age and the number of dental pulp cells. Regression analysis was carried out to create regression equations to estimate age from the number of dental pulp cells. Thirty sections were randomly chosen for intra-examiner and inter-examiner reliability test for cell count by intra-class correlation analysis. Estimated and chronological age was compared using t-test.

\section{Results}

\section{Odontoblasts, subodontoblasts and fibroblasts cell count at different age groups}

Fig. 1A shows a section of the dental pulp from where cell count of the dental pulp cells was carried out. The correlation values of the intra-examiner and inter-examiner reliability test for the cell count were good $(0.80-0.91 \& 0.78-0.86$, respectively). The highest number of cells were observed for all cell type (odontoblasts, subodontoblasts and fibroblasts) in the age group of 6-25 years and following this, the number of cells decreased with aging. The number of cells was significantly higher $(\mathrm{P}<0.001)$ in the age group of 6-25 years when compared to the age group of 26-80 years (Figs. 1B, 1C and 1D). 


\section{Correlation between age and odontoblasts, subodontoblasts and fibroblasts cell number}

Pearson correlation test revealed that there was a significant positive correlation between age and the dental pulp cell count (odontoblasts, subodontoblasts and fibroblasts) in the 6-25 years age group (Figs. 2A1, 2B1 and 2C1). In the 26-80 years age group, there was a significant negative correlation between age and the cell count of odontoblasts and subodontoblasts (Figs. 2A2, 2B2), but for fibroblasts there was negligible correlation (fibroblasts count remained unchanged along with ageing) (Fig. 2C2).

\section{Formulation of regression equations for estimating age}

Age estimation based on pulp cell count were investigated by generating regression equations obtained from regression analysis (Table 1). Regression analysis was carried out only for those age groups where there was statistically significant correlation between age and the cell count (Fig. 2). The standard error of estimates (SEEs) were around \pm 5 years and \pm 8 years for the $6-25$ years and 26-80 years age groups, respectively. The estimated age was then compared to the chronological age to understand the accuracy of the predicted age using the dental pulp cell count. The mean values between chronological and estimated age was not significantly different $(\mathrm{P}>0.5$, t-test).

\section{Discussion}

The dental pulp cell count for odontoblasts, subodontoblasts and fibroblasts were found to be the highest in the young age group and following this, a significant reduction in the cell count was observed for odontoblasts and subodontoblasts. Previous studies have reported that the reduction 
of the dental pulp cells with age occurs both in the crown and root region of the dental pulp (Daud, Nambiar, Hossain, Rahman \& Bakri, 2014; Murray, Stanley, Matthews, Sloan \& Smith, 2002). Understanding the effects of biological aging of the dental pulp will be important as the function of the dental pulp cells may be affected with age. When a tooth is exposed to an external stimulation, the odontoblasts may respond to the situation by forming tertiary dentine. The reparative potential of the odontoblast have been described in many studies (Bjørndal, Darvann \& Thylstrup, 1998; Goldberg \& Smith, 2004; Kawagishi, Nakakura-Ohshima, Nomura \& Ohshima, 2006). Ultrastructural studies of the human odontoblasts and its morphological changes have also been reported (Couve, 1986; Couve, Osorio \& Schmachtenberg, 2013; Daud, Nambiar, Hossain, Rahman \& Bakri, 2014) and therefore, it is anticipated that with aging the odontoblasts cell function may be affected. There are four histologically distinguished zones in the dental pulp. The outermost layer of the pulp consists of the odontoblasts and beneath this layer is the cell-free zone (zone of Weil) and this is followed by a cell-rich zone. When conducting the cell count for subodontoblasts, we observed that both the cell-free zone and the cell-rich zone, which have been described as the subodontoblastic layer, (Gotjamanos, 1969) were not always clearly demarcated. This has also been reported by Tomaszewska et al., 2013 who observed that the cell-free zone may often be absent while the cell-rich zone was always present but with some modification to its cellular elements (Tomaszewska, Miskowiak, Matthews-Brzozowska \& Wierzbicki, 2013). The reduction of the subodontoblasts with age will also have an effect on the tooth's ability to function in response to tooth injury. During tooth injury, the subodontoblasts are capable of differentiating to become odontoblast-like cells and contribute towards tooth repair activity. It was reported that the majority of the subodontoblasts expressed Thy-1, a cell-surface marker of stem and progenitor cells and had high potential to differentiate into hard tissue-forming cells (Hosoya et al., 2012). 
The loss of cells as indicated by the reduction in cell number for odontoblasts and subodontoblast with age would indicate that the pulp's capacity for tooth repair would be compromised in the elderly.

Generally, there was an increase of the cell number for fibroblasts in 6-25 years age group. After that, there was negligible reduction of fibroblasts from 26 to 80 years of age (Fig. 2C2), therefore, it is anticipated that the process of aging did not have much effect on the fibroblasts function with age. The fibroblasts are involved in maintaining the dental pulp matrix and producing collagen fibers. There are many types of collagen fibers; the thick fibers of collagen type I represent the main component of the connective tissue matrix of the dental pulp (Shuttleworth, Ward \& Hirschmann, 1978) while collagen type III has been described as one of the main fibrillar elements present in the dental pulp matrix (van Amerongen, Lemmens \& Tonino, 1983) and collagen type IV can be found at the basement membrane of blood vessels (Hillmann \& Geurtsen, 1997; Shuttleworth, Ward \& Hirschmann, 1978; van Amerongen, Lemmens \& Tonino, 1983; Yurchenco \& Ruben, 1988). As these and other types of collagen fibres are distributed in the dental pulp of all ages, this would suggest that with increasing age, the fibroblasts function in the development and maintenance of the dental pulp matrix may not be much affected.

Correlation tests were carried out to analyse the relationship between the subjects' age and the dental pulp cell numbers. While significant positive correlations between age and cell number were found in the 6-25-years age group for all types of the dental pulp cell, significant negative correlations were found for odontoblasts and subodontoblasts in the 26-80 years age group. This would suggest that it would be possible to use dental pulp cell count for estimating age. Regression equations were then generated from the two age groups and the formula was tested for age 
estimation using cell counts. Regression equations have practical applications and have been used widely in forensic sciences for estimating age/other parameters of unknown deceased individuals (Brkic, Milicevic \& Petrovecki, 2006; Hossain, Munawar, Rahim \& Bakri, 2016; Schmitt, SalibaSerre, Tremblay \& Martrille, 2010). When the regression equations were applied to estimate the age of individuals used in this study, the mean values of the estimated age was not significantly different (t-test, $\mathrm{P}>0.05$ ) than the mean values of the chronological age. However, as the SEEs were around \pm 5 years and \pm 8 years for the 6-25 years and 26-80 years age groups respectively, these findings indicate that regression equations obtained using dental pulp cell number can be used to predict age with certain limitations.

\section{Conclusions}

A significant correlation between the number of odontoblasts and subodontoblasts and age was demonstrated. Regression equations using odontoblasts or subodontoblasts cell count can be used to estimate age with some limitation.

\section{Acknowledgements}

This work was supported by the Fundamental Research Grant Scheme FPO20-2014A and University Malaya Research Grant RP036A-15HTM. 


\section{References}

Baume, L. J. (1980). The biology of pulp and dentine. A historic, terminologic-taxonomic, histologicbiochemical, embryonic and clinical survey. Monographs in oral science, 8, 1-220.

Bjørndal, L., Darvann, T., \& Thylstrup, A. (1998). A quantitative light microscopic study of the odontoblast and subodontoblastic reactions to active and arrested enamel caries without cavitation. Caries Res., 32(1), 59-69.

Brkic, H., Milicevic, M., \& Petrovecki, M. (2006). Age estimation methods using anthropological parameters on human teeth. Forensic Sci Int, 162(1-3), 13-16. doi:10.1016/j.forsciint.2006.06.022

Couve, E. (1986). Ultrastructural changes during the life cycle of human odontoblasts. Arch Oral Biol, 31(10), 643-651.

Couve, E., Osorio, R., \& Schmachtenberg, O. (2013). The amazing odontoblast: activity, autophagy, and aging. J Dent Res., 92(9), 765-772.

Couve, E., \& Schmachtenberg, O. (2011). Autophagic activity and aging in human odontoblasts. J Dent Res, 90(4), 523-528. doi:10.1177/0022034510393347

Daud, S., Nambiar, P., Hossain, M. Z., Rahman, M. R., \& Bakri, M. M. (2014). Changes in cell density and morphology of selected cells of the aging human dental pulp. Gerodontology. doi:10.1111/ger.12154.

Daud S, Nambiar P, Hossain MZ, Saub R, Ab-Murat, Asma' M, Razak FA, \& Bakri MM (2016). Removal of the apical one-third of the root improves the fixation process of the dental pulp in teeth, Journal of Histotechnology, 39:3, 81-87. doi: 10.1080/01478885.2016.1164377

Demirjian, A., Goldstein, H., \& Tanner, J. M. (1973). A new system of dental age assessment. Hum Biol, 45(2), 211-227.

Goldberg, M., \& Smith, A. J. (2004). Cells and Extracellular Matrices of Dentin and Pulp: A Biological Basis for Repair and Tissue Engineering. Crit Rev Oral Biol Med., 15(1), 13-27.

Gotjamanos, T. (1969). Cellular organization in the subodontoblastic zone of the dental pulp. I. A study of cell-free and cell-rich layers in pulps of adult rat and deciduous monkey teeth. Arch Oral Biol., 14(9), 1007-1010.

Grosskopf, B., \& McGlynn, G. (2011). Age diagnosis based on incremental lines in dental cementum: a critical reflection. Anthropologischer Anzeiger; Bericht uber die biologisch-anthropologische Literatur, 68(3), 275-289.

Gustafson, G. (1950). Age determination on teeth. J Am Dent Assoc, 41(1), 45-54.

Hillmann, G., \& Geurtsen, W. (1997). Light-microscopical investigation of the distribution of extracellular matrix molecules and calcifications in human dental pulps of various ages. Cell Tissue Res., 289(1), 145-154.

Hosoya, A., Hiraga, T., Ninomiya, T., Yukita, A., Yoshiba, K., Yoshiba, N., Takahashi, M., Ito, S., \& Nakamura, H. (2012). Thy-1-positive cells in the subodontoblastic layer possess high potential to differentiate into hard tissue-forming cells. Histochem Cell Biol, 137(6), 733-742. doi:10.1007/s00418-0120928-1

Hossain, M. Z., Munawar, K. M., Rahim, Z. H., \& Bakri, M. M. (2016). Can stature be estimated from tooth crown dimensions? A study in a sample of South-East Asians. Arch Oral Biol, 64, 85-91. doi:10.1016/j.archoralbio.2016.01.001

Johanson, G. (1971). Age determination from human teeth. Odontologisk Revy, 22, (Supp), 22.

Kawagishi, E., Nakakura-Ohshima, K., Nomura, S., \& Ohshima, H. (2006). Pulpal responses to cavity preparation in aged rat molars. Cell Tissue Res, 326(1), 111-122. doi:10.1007/s00441-006-0230-4 
Logan, W. H. G., \& Kronfeld, R. (1933). Development of the human jaws and surrounding structures from birth to the age of fifteen years. J Am Dent Assoc, 20, 379.

Metzger, Z., Buchner, A., \& Gorsky, M. (1980). Gustafson's method for age determination from teeth--a modification for the use of dentists in identification teams. J Forensic Sci, 25(4), 742-749.

Moorrees, C. F., Fanning, E. A., \& Hunt, E. E., Jr. (1963). Age Variation of Formation Stages for Ten Permanent Teeth. J Dent Res, 42, 1490-1502.

Murray, P. E., Matthews, J. B., Sloan, A. J., \& Smith, A. J. (2002). Analysis of incisor pulp cell populations in Wistar rats of different ages. Arch Oral Biol, 47(10), 709-715.

Murray, P. E., Stanley, H. R., Matthews, J. B., Sloan, A. J., \& Smith, A. J. (2002). Age-related odontometric changes of human teeth. Oral Surg Oral Med Oral Pathol Oral Radiol Endod, 93(4), 474-482.

Nanci, A. (2012). Ten cate's oral histology development structure and function.: Mosby.

Pillai, P. S., \& Bhaskar, G. R. (1974). Age estimation from teeth using Gustafson's method--a study in India. Forensic Sci, 3(2), 135-141.

Schmitt, A., Saliba-Serre, B., Tremblay, M., \& Martrille, L. (2010). An evaluation of statistical methods for the determination of age of death using dental root translucency and periodontosis. $J$ Forensic Sci, 55(3), 590-596. doi:10.1111/j.1556-4029.2010.01341.x

Shuttleworth, C. A., Ward, J. L., \& Hirschmann, P. N. (1978). The presence of type III collagen in the developing tooth. Biochim Biophys Acta., 535(2), 548-555.

Solheim, T. (1992). Amount of secondary dentin as an indicator of age. Scand J Dent Res, 100(4), 193-199.

Stanley, H. R., White, C. L., \& McCray, L. (1966). The rate of tertiary (reparative) dentine formation in the human tooth. Oral Surg Oral Med Oral Pathol, 21(2), 180-189.

Takuma, S., \& Nagai, N. (1971). Ultrastructure of rat odontoblasts in various stages of their development and maturation. Arch Oral Biol, 16(9), 993-1011.

Tomaszewska, J. M., Miskowiak, B., Matthews-Brzozowska, T., \& Wierzbicki, P. (2013). Characteristics of dental pulp in human upper first premolar teeth based on immunohistochemical and morphometric examinations. Folia Histochem Cytobiol., 51(2), 149-155.

Tziafas, D., \& Kodonas, K. (2010). Differentiation potential of dental papilla, dental pulp, and apical papilla progenitor cells. J Endod, 36(5), 781-789. doi:10.1016/j.joen.2010.02.006

van Amerongen, J. P., Lemmens, I. G., \& Tonino, G. J. (1983). The concentration, extractability and characterization of collagen in human dental pulp. Arch Oral Biol., 28(4), 339-345.

Whittaker, D. K., \& Bakri, M. M. (1996). Racial variations in the extent of tooth root translucency in ageing individuals. Arch Oral Biol, 41(1), 15-19.

Yurchenco, P. D., \& Ruben, G. C. (1988). Type IV collagen lateral associations in the EHS tumor matrix. Comparison with amniotic and in vitro networks. Am J Pathol., 132(2), 278-291. 


\section{Figure captions}

Fig.1. A. Histological section of the dental pulp showing location of the dental pulp cell count for odontoblasts, subodontoblasts and fibroblasts. B-D, cell number for odontoblasts (B), subodontoblasts (C) and fibroblasts (D) at 6-25 years and 26-80-years.* $(\mathrm{P}<0.001)$

Fig. 1

A

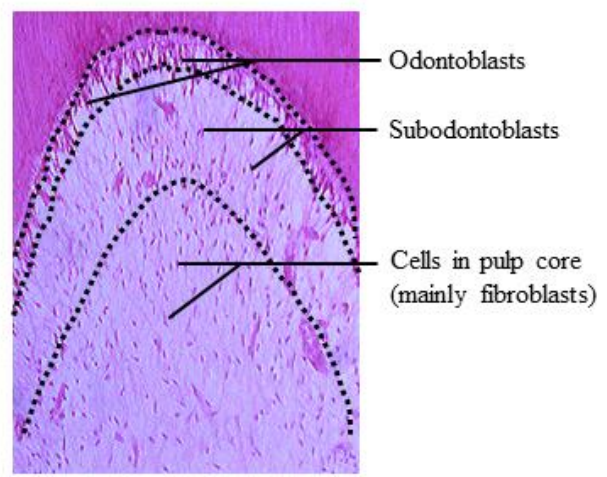

C

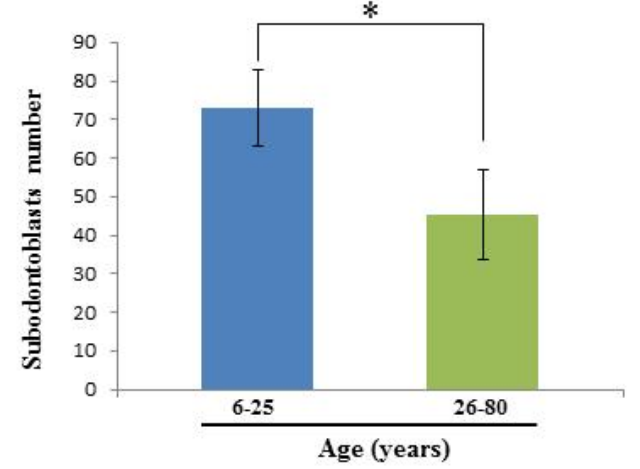

B

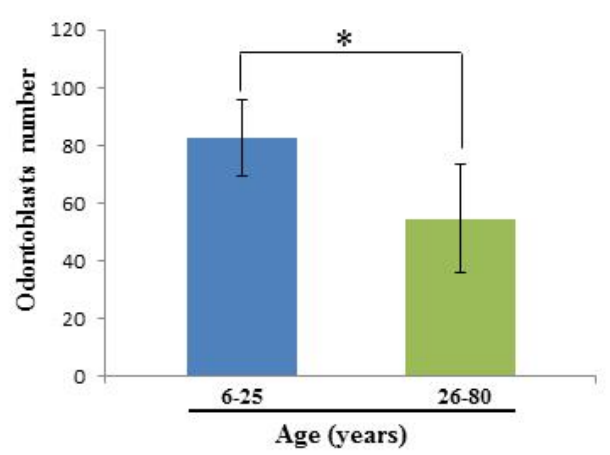

D

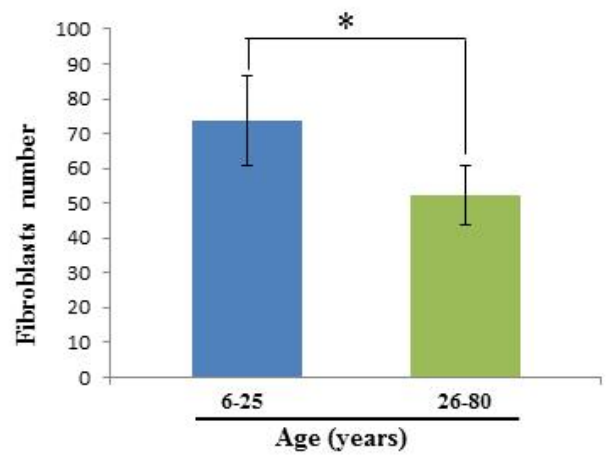


Fig 2. Correlation between cell number for odontoblasts (AI and A2), subodontoblasts (BI and B2) and fibroblasts ( $\mathrm{C} 1$ and $\mathrm{C} 2)$ at 6-25 years and 26-80 years age groups respectively.

Fig. 2
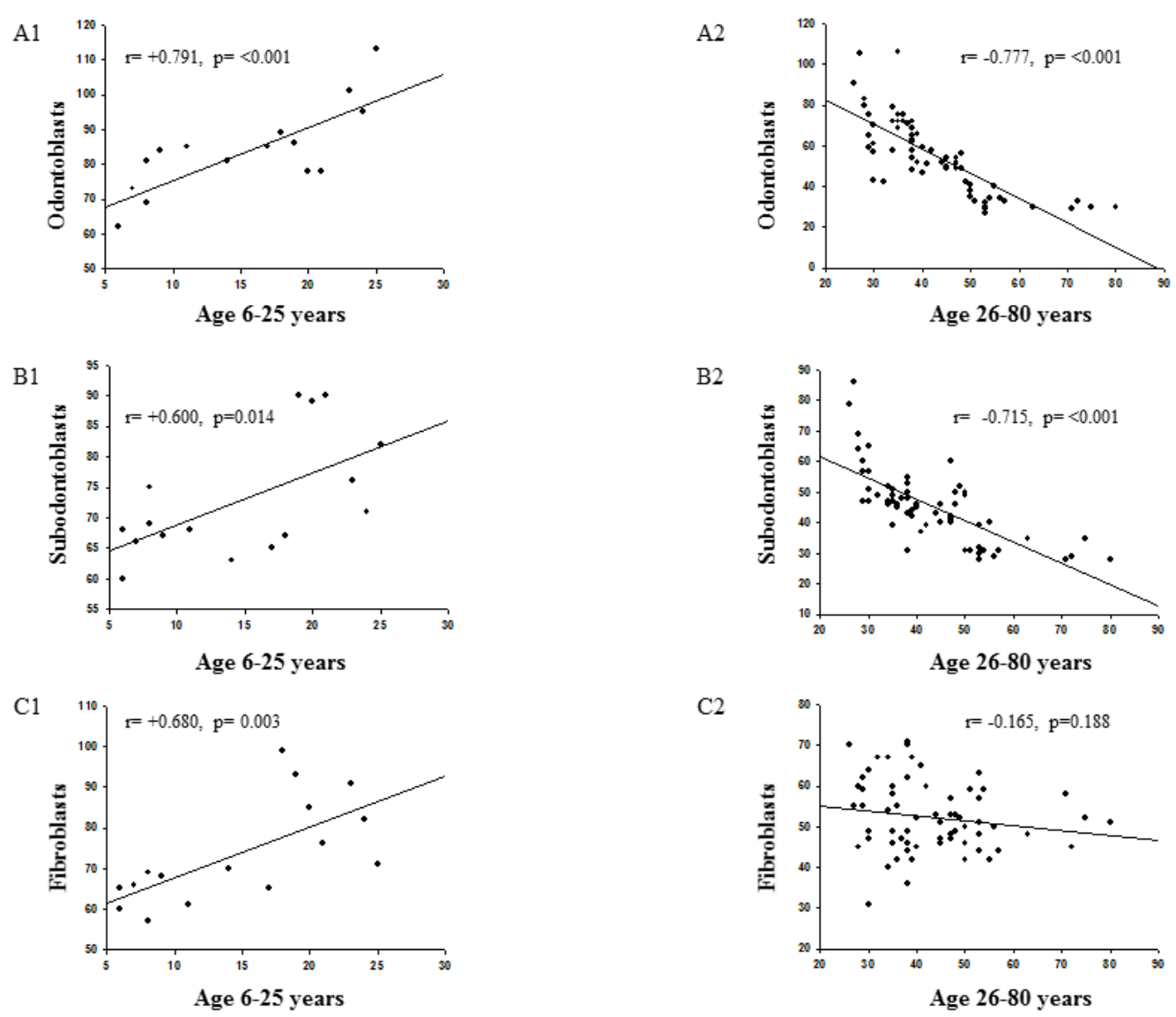
Table 1: Regression equations (RE) and standard error of estimate (SEE) for age estimation from the dental pulp cell count

\begin{tabular}{lllll}
\hline Cells in pulp & Age 6-25 years & \multicolumn{3}{l}{ Age 26-80 years } \\
& RE & SEE & RE & SEE \\
\cline { 2 - 5 } & & & & \\
\hline Odontoblasts & Age $=-19.084+(0.409$ & \pm 4.356 & Age $=70.437-(0.500 \times$ & \pm .604 \\
& $\times$ Odontoblasts $)$ & years & Odontoblasts $)$ & years \\
& & & & \\
\hline Subodontoblasts & Age $=-15.846+(0.420$ & \pm 5.702 & Age $=76.450-(0.734 \times$ & \pm 8.447 \\
& $\times$ Subodontoblasts $)$ & years & Subodontoblasts $)$ & years \\
& & & & \\
& & & & - \\
\hline Fibroblasts & Age $=-12.347+(0.368$ & \pm 5.225 & - & \\
& $\times$ Fibroblasts $)$ & years & & \\
\hline
\end{tabular}

